\title{
Effect of immunization against synthetic peptide sequences of bovine inhibin $\alpha$-subunit on ovulation rate and twin-calving rate in heifers
}

\author{
D. G. Morris ${ }^{1}$, M. G. McDermott ${ }^{1}$, M. G. Diskin ${ }^{1}$, C. A. Morrison ${ }^{2}$, \\ P. J. Swift ${ }^{3}$ and J. M. Sreenan ${ }^{1}$ \\ ${ }^{1}$ Animal Reproduction Department, Agriculture and Food Development Authority, Belclare, Tuam, \\ Co. Galway, Ireland; ' ${ }^{C}$ Ciba-Geigy Animal Health Ltd, Centre de Recherches Agricoles, CH-1566 \\ St Aubin, Switzerland; and ${ }^{3} \mathrm{Ciba-Geigy}$ Animal Health Ltd, Ciba-Geigy Ltd, CH-4002 Basel, \\ Switzerland
}

\begin{abstract}
Three peptide sequences from the bovine inhibin $\alpha$-subunit (P1: 18-30; P2: 63-72 and P3: 107-122) were synthesized and conjugated to human serum albumin (HSA). Hereford crossheifers ( $n=5$ per group) were injected with $3 \mathrm{mg}$ of one of the peptide conjugates, followed by three booster injections at intervals of 11 weeks. Control heifers $(n=5)$ were injected with HSA only. Antibodies recognizing both the individual peptides and $32 \mathrm{kDa}$ bovine inhibin were generated and ovulation rate was increased in peptide immunized heifers. In group P1, 1 of 5 heifers responded with an increased ovulation rate whereas in groups P2 and P 3,5 of 5 and 4 of 5 heifers, respectively, had an increased ovulation rate. In group P2, in the first oestrous cycle following booster injections 2 and 3, 4 of 5 and 3 of 5 heifers, respectively, responded with twin ovulations, whereas a fourth heifer had three ovulations following booster injection 3. After breeding following booster injection 3, 3 of 5 heifers in group $\mathrm{P} 2$ and 1 of 5 in group P3 gave birth to twin calves. This study demonstrates the potential of immunizing against synthetic peptide sequences of the $\alpha$-subunit of bovine inhibin to increase ovulation and twinning rates in cattle.
\end{abstract}

\section{Introduction}

Inhibin is a dimeric protein hormone composed of two dissimilar, disulfide-linked subunits (termed $\alpha$ and $\beta$ ), and is involved in the negative feedback regulation of gonadotrophin secretion, preferentially follicle-stimulating hormone (FSH) (Burger and Igarashi, 1988; Ying, 1988). Interference with this negative feedback by active immunization against either partly purified inhibin (O'Shea et al., 1984; Morris et al., 1991), recombinant inhibin (Forage et al., 1987; Mizumachi et al., 1990) or synthetic inhibin peptides (Wrathall et al., 1990; Boland et al., 1991) resulted in significant and consistent increases in ovulation rate in sheep. An increased ovulation rate has also been recorded following immunization of cattle against either partly purified inhibin (Price et al., 1987; Sreenan et al., 1987) or a synthetic inhibin peptide (Glencross et al., 1990; Sunderland et al., 1991). An increase in litter size has also been reported following immunization of sheep against either partly purified (O'Shea et al., 1984) or recombinant bovine inhibin (Tsonis et al., 1989). There are no published data on calving or twinning rates in cattle following immunization against inhibin.

This paper describes the effect of active immunization of heifers against each of three synthetic peptide sequences from the bovine inhibin $\alpha$-subunit on peptide antibody titre, inhibin binding, ovulation rate, calving rate and twin-calving rate.

\section{Materials and Methods}

\section{Sequence identification}

The amino acid sequence of the bovine inhibin $\alpha$-subunit (Forage et al., 1986) was analysed by the methods of Chou and Fasman (1978) and Kyte and Doolittle (1982), using a computer program assembled by Mammi (1989). This program combines algorithms for the prediction of hydrophilicity/hydrophobicity and secondary structure, and enables the rapid identification of likely immunological epitopes. Three peptide sequences (Fig. 1) were identified as potential antigenic sites. The natural sequences were modified during synthesis by the addition of either tyrosyl or cystenyl residues, linked through a glycine spacer where appropriate, to facilitate iodination and conjugation, respectively.

\section{Peptide synthesis}

The crude peptides were synthesized on methylbenzhydrylamine resin using an ACT (Advanced Chemical Technology, Louisville, KY) series 200 automated system. Free peptide amides were cleaved from the resin by treatment with hydrogen fluoride/ anisole or hydrogen fluoride/metacresol and purified by gel filtration on Sephadex G-25 (Pharmacia LKB, Milton Keynes) followed by preparative high pressure liquid chromatography (HPLC) on $1.5 \times 45 \mathrm{~cm}$ columns of silica $(10-15 \mu \mathrm{m}$, Vydac C18, The Separations Group, Hesperia, CA). Peptide purity was assessed by analytical HPLC, thin layer chromatography (TLC) 
and amino acid analysis of acid hydrolysates. The purity of each peptide was greater than $90 \%$.

\section{Peptide conjugation}

Each peptide was conjugated to human serum albumin (HSA) and conalbumin (Sigma, Poole, Dorset) as follows. HSA or conalbumin $(100 \mathrm{mg}$ ) was dissolved in $0.5 \mathrm{ml} 0.2 \mathrm{~mol}$ sodium borate $1^{-1}, 0.15 \mathrm{~mol} \mathrm{NaCl} 1^{-1}, \mathrm{pH} 8.3$ and reacted at $23^{\circ} \mathrm{C}$ for $5 \mathrm{~min}$ with $9.0 \mathrm{mg}$ of $N$ - $\gamma$-maleimido-butyryloxysuccinimide (GMBS; Calbiochem, Lucerne) dissolved in $20 \mu \mathrm{l}$ of dry freshly distilled dimethylformamide. Samples were then centrifuged for $1 \mathrm{~min}$ in an Eppendorf microfuge ( $15000 \mathrm{~g}$ ) and desalted immediately on a column $(0.9 \times 30 \mathrm{~cm})$ of Sephadex G-25, equilibrated with de-gassed 0.1 mol Hepes $1^{-1}, \mathrm{pH} 7.0$. The modified protein eluting in the void volume was transferred to a stoppered vial, and $10 \mathrm{mg}$ inhibin peptide, dissolved in 0.1 mol Hepes $1^{-1}$ just before addition, was added a drop at a time. The mixture was stirred at $23^{\circ} \mathrm{C}$ for $4 \mathrm{~h}$ and at $4^{\circ} \mathrm{C}$ overnight before dialysis

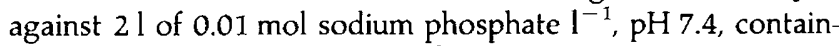
ing 0.15 mol sodium chloride $\mathrm{l}^{-1}$ (three changes), using Spectra Por 1 membrane (cut off $M_{r} 6000-8000$; Spectrum Med. Ind., Los Angeles, CA). The extent of protein substitution by peptide was estimated by analysing the complexes on an $8-25 \%$ gradient sodium dodecylsulfate polyacrylamide gel electrophoresis (SDS-PAGE) (Phastsystem; Pharmacia LKB). For each complex approximately $6-8 \mathrm{~mol}$ of peptide were bound per mole of carrier. Peptide conjugates were stored as lyophilized powders at $-25^{\circ} \mathrm{C}$ until required for immunization.

\section{Immunization}

Twenty nulliparous Hereford cross-heifers, approximately 18 months of age and $367 \pm 7 \mathrm{~kg}$ (mean \pm SEM), were randomly allotted in equal numbers $(n=5)$ to three treatment groups and a control group. Inhibin peptide-HSA conjugates $(3 \mathrm{mg}$ ) were dissolved in $2 \mathrm{ml}$ saline $(0.85 \% \mathrm{NaCl})$, emulsified in an equal quantity of Freund's complete adjuvant (Difco, Detroit, MI) and injected into four sites in the brisket region. Three booster injections (1.5mg of conjugate) were similarly prepared but emulsified in non-ulcerative Freund's adjuvant (NUFA; Guildhea Antisera, Guildford, Surrey) and administered at intervals of 11 weeks. The control group was immunized with HSA carrier only. The second and third booster injections were given to all groups between day 7 and day 19 of the oestrous cycle. Blood samples were taken immediately before (pre-immune) and at regular intervals after immunization (immune) by jugular venepuncture. The blood samples were taken into $10 \mathrm{ml}$ tubes without additive (Vacutainer; Beckton and Dickinson, UK) and allowed to clot for $1 \mathrm{~h}$ at $37^{\circ} \mathrm{C}$. After centrifugation, the serum was removed and stored at $-25^{\circ} \mathrm{C}$ until assay for anti-peptide antibodies using a solid phase enzymeimmunoassay and for anti-bovine $32 \mathrm{kDa}$ inhibin antibodies using a solution phase radioimmunoassay.

\section{Enzymeimmunoassay procedure}

Microtitre plate wells (No. 3590; Costar, High Wycombe, Bucks) were coated with $100 \mu \mathrm{l}$ of a $2 \mu \mathrm{moll}^{-1}$ solution (as peptide) of peptide-conalbumin conjugate in $0.05 \mathrm{~mol}$ sodium bicarbonate $\mathrm{l}^{-1}, \mathrm{pH}$ 9.6. After incubation for $2 \mathrm{~h}$ at $37^{\circ} \mathrm{C}$, the

$$
\begin{array}{lll}
1 & \text { P1: } & \text { bI }-\alpha-\mathrm{Ty}^{16} \mathrm{Gl}^{17}(18-30): \text { YGQRPPEEPAAHADC } \\
2 & \text { P2: bI } \alpha-(63-72) G l \mathrm{y}^{73} \mathrm{Ty}^{74}: \text { CGLSPPQDLPGY } \\
3 & \text { P3: bI } \alpha-\mathrm{Cys}^{105} \mathrm{Gly}^{106}(107-122): \text { CGHVRTTSDGGYSFKYEM }
\end{array}
$$

Fig. 1. Sequences of the synthetic peptides derived from the bovine $\alpha$ inhibin subunit.

plates were washed three times with $100 \mathrm{mmol}$ sodium phosphate $1^{-1}, \mathrm{pH} 7.4(\mathrm{~PB})$ containing $0.15 \mathrm{~mol} \mathrm{NaCl}^{-1}$ (PBS). Plate wells were blocked with $1 \%(\mathrm{w} / \mathrm{v})$ ovalbumin $(\mathrm{BDH}$, Poole, Dorset) in PBS (PBSO) and incubated for $4 \mathrm{~h}$ at $37^{\circ} \mathrm{C}$ and overnight at room temperature. The plates were then washed with $\mathrm{PB}$ containing $1.0 \mathrm{~mol} \mathrm{NaCl} \mathrm{l}{ }^{-1}$ and $0.3 \%(w / v)$ Tween-20 (PBST); $100 \mu \mathrm{l}$ of pre- and immune-serum, diluted in PBSO containing $0.05 \%(\mathrm{w} / \mathrm{v})$ Tween-20, was added to each well in duplicate and incubated for $2 \mathrm{~h}$ at $37^{\circ} \mathrm{C}$. After washing as before, the wells were further incubated for $1 \mathrm{~h}$ at $37^{\circ} \mathrm{C}$ with $100 \mu \mathrm{l}$ horseradish peroxidase labelled rabbit anti-bovine immunoglobulin (Dakopatts, Glostrup, DK) diluted 1:8000 in PB containing $0.3 \mathrm{~mol} \mathrm{NaCl} 1^{-1}, 0.05 \%(\mathrm{w} / \mathrm{v})$ Tween-20 and $2 \%$ normal rabbit serum. After a further washing, the wells were incubated for $30 \mathrm{~min}$ at room temperature with $150 \mu \mathrm{l}$ of $1.5 \mathrm{mg} o$-phenylenediamine $\mathrm{ml}^{-1}, 5 \mathrm{mmol} \mathrm{H}_{2} \mathrm{O}_{2} \mathrm{l}^{-1}$ in $0.05 \mathrm{~mol}$ phosphocitrate $\mathrm{l}^{-1}$, $\mathrm{pH}$ 5.0. The reaction was stopped by the addition of $50 \mu \mathrm{l} 4 \mathrm{~mol}$ $\mathrm{H}_{2} \mathrm{SO}_{4} \mathrm{I}^{-1}$ and the absorbance of each well was measured at $492 \mathrm{~nm}$ on an enzyme-linked immunosorbant assay (ELISA) reader (MR580; Dynatech, Billingshurst). Titre was expressed as the reciprocal dilution of serum required to give an absorbance of 0.5 under the assay conditions used.

\section{Radioimmunoassay procedure}

Inhibin iodination. Bovine $32 \mathrm{kDa}$ inhibin was radiolabelled with ${ }^{125}$ I to a specific activity of approximately $24 \mu \mathrm{Ci} \mu \mathrm{g}^{-1}$ by a modification of the chloramine-T method of Greenwood et al. (1963). Briefly, $5 \mu \mathrm{g}$ of essentially pure biologically active bovine inhibin (Peninsula Laboratories, UK) was dissolved in $10 \mu \mathrm{l}$ of $0.1 \%(\mathrm{v} / \mathrm{v})$ trifluoroacetic acid in distilled water and added to a $1 \mathrm{ml}$ Eppendorf tube containing $20 \mu \mathrm{l} 0.5 \mathrm{~mol} \mathrm{~PB} \mathrm{I}^{-1}$, $\mathrm{pH}$ 7.5. To this, $1 \mathrm{mCi}(10 \mu \mathrm{l})$ of $\left.\mathrm{Na}{ }^{125} \mathrm{I}\right]$ (IMS 30; Amersham Int., Bucks) was added followed by $10 \mu$ l chloramine $T$ in PB $\left(0.2 \mathrm{mg} \mathrm{ml}^{-1}\right)$. After vortexing for $1 \mathrm{~min}, 50 \mu \mathrm{l}$ of tyrosine in $\mathrm{PB}$ $\left(0.4 \mathrm{mg} \mathrm{ml}^{-1}\right)$ was added and vortexed for $15 \mathrm{~s}$. The mixture was then applied to a Sephadex G-75 (Pharmacia LKB) column $(50 \times 1 \mathrm{~cm})$ pre-equilibrated with $10 \mathrm{mg} \mathrm{BSA}$, and eluted with 0.05 mol Tris- $\mathrm{HCl} \mathrm{l}^{-1}, \mathrm{pH} 7.5$ containing $8 \mathrm{~mol}^{-1}$ urea $\mathrm{l}^{-1}$ and $5 \mathrm{mmol} 3$-[(cholamidopropyl)-dimethyl-ammonio]-1-propanesulfonate (Chaps) $\mathrm{l}^{-1}$. Suitable dilutions of the inhibin containing fractions eluted were assessed for binding by incubating with chicken anti-inhibin antiserum (H95/2; Knight et al., 1989) in an optimized radioimmunoassay, and were characterized with regard to molecular weight by $8-18 \%$ gradient SDS-PAGE (ExcelGel SDS; Pharmacia LKB) and autoradiography on Hyperfilm $\beta$-max (Amersham Int.). Maximally binding fractions were associated with a $32 \mathrm{kDa}$ protein that migrated as two subunits of 20 and $12 \mathrm{kDa}$ under reducing conditions, which is consistent with the known structure for bovine inhibin.

Inhibin binding. $\quad\left[{ }^{125} \mathrm{I}\right]$-labelled inhibin (100 $\mu \mathrm{l} ; 10000$ d.p.m.) diluted in $50 \mathrm{mmol}$ sodium phosphate $1^{-1} \mathrm{pH} 7.4$ containing 
$0.15 \mathrm{mmol} \mathrm{NaCl} \mathrm{l}^{-1}$ and $0.1 \%$ ovalbumin was incubated with $100 \mu \mathrm{l}$ of serum (final dilution 1:40) from immunized heifers for $24 \mathrm{~h}$ at $20^{\circ} \mathrm{C}$. Antibody bound label was then precipitated by adding $400 \mu \mathrm{l}$ of ice-cold $20 \%$ polyethylene glycol (PEG, MW$6000 ; \mathrm{BDH}$ ) to each tube. After $30 \mathrm{~min}$ at $4{ }^{\circ} \mathrm{C}, 3 \mathrm{ml}$ of $13 \%$ PEG was added to each tube and the tubes were centrifuged for $30 \mathrm{~min}$ at $4000 \mathrm{~g}$. The radioactivity in the pellet was counted in a $\gamma$-counter (Multigamma 1261; Pharmacia LKB). Binding was expressed as the percentage of radiolabel bound relative to total counts added (\%B:T) after correction for nonspecific binding by pre-immune serum.

\section{Oestrous and ovarian responses}

Five days after each booster injection, the oestrous cycles of the heifers were synchronized with a short-term (9-day) progestagen (Sreenan and Mulvehill, 1975). Twenty-four hours before pessary removal, each heifer received a luteolytic dose (15 mg) of Luprositol (Prosolvin; Intervet, Cambridge, UK) intramuscularly. At progestagen removal, heifers were tail-painted to aid detection of oestrus and were observed four times a day for standing oestrus. Ultrasonography (DSL $300,5 \mathrm{MHz}$ probe; Diagnostic Sonar, Livingston, Scotland) was carried out between day 6 and day 10 on all heifers during each oestrous cycle to determine the number of corpora lutea present.

\section{Conception and calving rate}

At the synchronized and first repeat oestrus following booster injection 3, heifers were mated. The number of fetuses present at 45 days after mating was counted by ultrasonography and at parturition the number of calves born was recorded.

\section{Statistical analysis}

The data were analysed using least squares ANOVA procedures (Harvey, 1987). Before analysis, peptide titre and percentage inhibin binding were transformed by log and angular transformations, respectively, to approximate normal variates. The model recognized that repeated measurements were made on the same heifers over time and included the effect of immunization treatment, heifers within treatment, booster injection number, cycle number and the interaction of treatment with cycle number. The treatment by cycle interaction was analysed in more detail, by comparing both cycle number after booster injection within treatment, and treatment within cycle number after booster injection using the Student-Newman-Keuls test. Because ovarian measurements during a fourth oestrous cycle were made on only a small number of heifers, these observations were assigned to cycle number three for analysis of variance. As inhibin binding, but not peptide titre, was common to all groups, it was the only between group parameter of the immune response that was analysed statistically. Correlations between ovulation rate in the first oestrous cycle following a booster injection, peptide titre and inhibin binding at 14 days after a booster injection (2-3 days before oestrus) were examined by regression analysis. The significance of the differences among these correlations was examined by testing the homogeneity of the regression of ovulation rate on titre. Inhibin binding is presented after back-transformation.

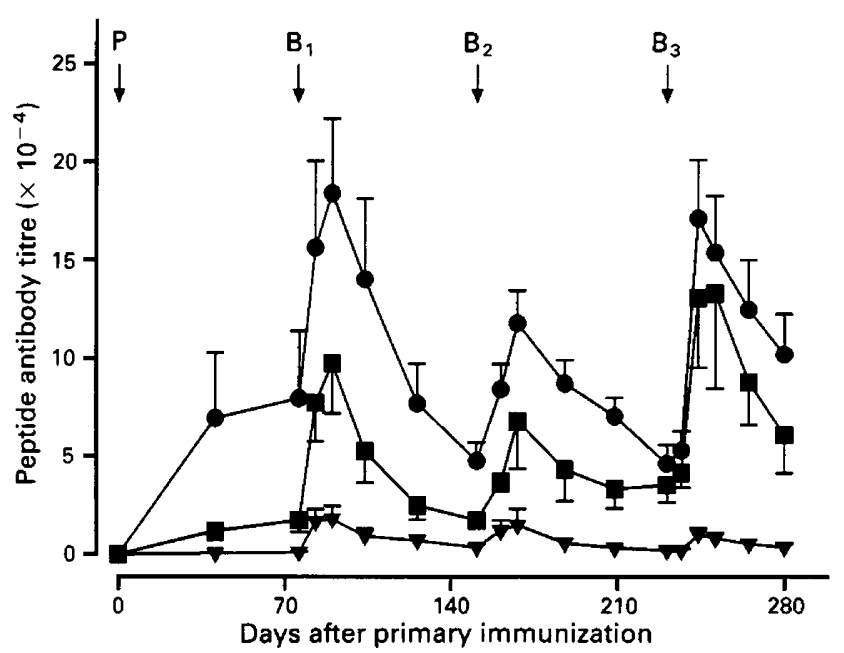

Fig. 2. Peptide antibody titres (means $\pm S E M$ ) in serum from heifers immunized against inhibin peptides ( $\boldsymbol{\square}$ ) P1, ( ) P2 and ( $\boldsymbol{\nabla}$ ) P3. Heifers were injected at intervals of 11 weeks (arrows). P: primary immunization; $\mathrm{B}_{1}-\mathrm{B}_{3}$ : consecutive booster injections.

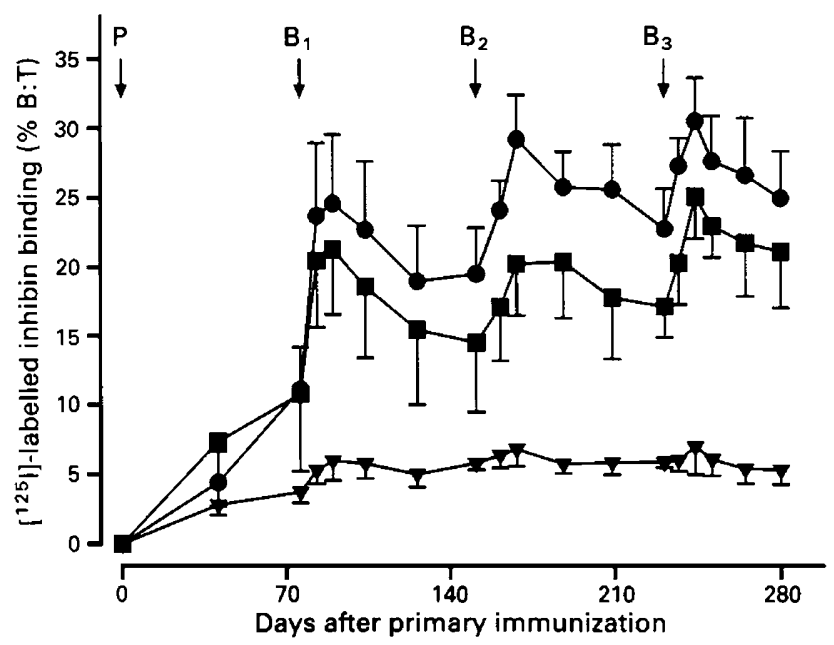

Fig. 3. Percentage binding (means \pm SEM) of ${ }^{125}$ I-labelled $32 \mathrm{kDa}$ bovine inhibin by serum from heifers immunized against inhibin peptides ( $\square$ )P1, (O)P2 and ( $\mathbf{\nabla}$ )P3. Heifers were injected at intervals of 11 weeks (arrows). $P$ : primary immunization; $\mathrm{B}_{1}-\mathrm{B}_{3}$ : consecutive booster injections.

\section{Results}

\section{Immune response}

Antibodies were generated to each of the peptides and titres reached a maximum value between 7 and 21 days following a booster injection (Fig. 2). The highest peptide titres recorded for individual animals within groups P1, P2 and P3 were 316000 , 284000 and 59000 , respectively. Peptide titres measured in the HSA-immunized control heifers and in pre-immune sera were less than 100 .

All heifers immunized with peptides generated antibodies that bound to inhibin, and binding reached a maximum between 7 and 21 days after a booster injection (Fig. 3). The highest 
Table 1. Specific inhibin binding (\%) 14 days after immunization of heifers with inhibin peptides

\begin{tabular}{lcc}
\hline Group & \multicolumn{2}{c}{ Inhibin binding (\%) } \\
\hline P1 & $21.5^{\mathrm{a}}$ & $16.5-27.1$ \\
& $(15)$ & $(4.6-35.0)$ \\
P2 & $27.5^{\mathrm{b}}$ & $22.0-33.5$ \\
& $(15)$ & $(6.4-42.2)$ \\
P3 & $5.5^{\mathrm{c}}$ & $2.9-8.8$ \\
& $(15)$ & $(1.1-13.4)$ \\
\hline
\end{tabular}

Values are means followed by $95 \%$ confidence limits of the mean of three booster injections with numbers of observations in parentheses followed by the range. $\mathrm{b}>\mathrm{a} P<0.05 ; \mathrm{a}, \mathrm{b}>\mathrm{c} P<0.01$.

$\left[{ }^{125} \mathrm{I}\right] 32 \mathrm{kDa}$ bovine inhibin binding recorded was $35 \%, 42 \%$ and 13\% (1:40 dilution) for individual heifers within groups P1, P2 and P3, respectively. Inhibin binding in HSA immunized heifers and in pre-immune sera was less than $2 \%$.

Booster injection number did not affect $(P>0.05)$ the percentage of radiolabelled inhibin bound 14 days after a boost. There were significant differences among the peptide immunized groups in the percentage of radiolabelled inhibin bound at 14 days after a booster injection (Table 1) with $\mathrm{P} 2$ exhibiting the highest binding. Peptide and inhibin titres were correlated for groups $\mathrm{PI}(r=0.46$, d.f. $=68, P<0.01)$ and $\mathrm{P} 2(r=0.74$, d.f. $=68, P<0.01)$ but not for group P3 $(r=-0.14$, d.f. $=68, P>0.05)$.

\section{Oestrous and owarian response}

The proportion of heifers showing oestrus was not affected $(P>0.05)$ by peptide immunization. Duration of oestrous cycle (least squares mean \pm SEM) for groups P1, P2, P3 and the control group was $19.8 \pm 0.5,20.3 \pm 0.6,19.2 \pm 0.3$ and $20.6 \pm 0.3$ days, respectively $(P>0.05)$.

Peptide immunization increased $(P<0.05)$ the ovulation rate overall; however, there was no difference among peptide groups $(P>0.05)$ (Table 2$)$. In the control group the ovulation rate was 1.0 at each cycle throughout the immunization period. Ovulation rate was increased in 1 of 5,5 of 5 and 4 of 5 of the heifers and in 6 of $38(16 \%), 13$ of $37(35 \%)$ and 6 of $33(18 \%)$ of the ovulatory cycles observed following immunization against $\mathrm{P} 1, \mathrm{P} 2$ and $\mathrm{P} 3$, respectively. Of the 25 multiple ovulatory cycles recorded, $19(76 \%)$ were twin ovulatory. Booster injection number did not affect ovulation rate $(P>0.05)$. However, there was a significant $(P<0.05)$ effect of cycle number on ovulation rate and also a significant $(P<0.005)$ treatment by cycle interaction (Table 3). One heifer (No. 13, P3) became anovulatory for 60-70 days after booster injection 2 . Within groups, peptide titre and ovulation rate were not correlated $(P>0.05)$. The within group correlations between inhibin binding and ovulation rate were $r=0.39$, d.f. $=14, P>0.05$ for group P1, $r=0.56$, d.f. $=13, P<0.05$ for group P2 and $r=-0.57$, d.f. $=11, P<0.05$ for group $\mathrm{P} 3$, revealing significant heterogeneity $(P<0.05)$.
Table 2. Number of ovulations in successive oestrous cycles following each of three booster injections for peptide immunized and control groups

\begin{tabular}{|c|c|c|c|c|c|c|c|c|c|c|c|}
\hline \multirow[b]{4}{*}{ Group } & \multirow{4}{*}{$\begin{array}{l}\text { Heifer } \\
\text { number }\end{array}$} & \multicolumn{10}{|c|}{ Booster injection number } \\
\hline & & \multicolumn{4}{|c|}{1} & \multicolumn{4}{|c|}{2} & \multicolumn{2}{|c|}{3} \\
\hline & & \multicolumn{10}{|c|}{ Cycle number } \\
\hline & & 1 & 2 & 3 & 4 & 1 & 2 & 3 & 4 & 1 & 2 \\
\hline \multirow[t]{5}{*}{ P1 } & 1 & 1 & 1 & 1 & $一^{*}$ & 1 & - & 1 & - & 1 & - \\
\hline & 2 & 2 & 1 & 4 & - & 1 & 3 & 2 & 一 & 3 & 4 \\
\hline & 3 & 1 & 1 & 1 & - & 1 & 1 & 1 & - & 1 & - \\
\hline & 4 & 1 & 1 & 1 & 1 & $\mathbf{I}$ & 1 & 1 & - & 1 & - \\
\hline & 5 & 1 & 1 & 1 & - & 1 & $\mathfrak{I}$ & 1 & 1 & 1 & 1 \\
\hline \multirow[t]{5}{*}{ P2 } & 6 & 2 & 1 & 1 & 1 & 2 & $\mathrm{I}$ & 1 & - & 3 & 2 \\
\hline & 7 & 1 & 1 & 1 & 1 & 2 & 1 & 1 & - & 1 & - \\
\hline & 8 & of & 1 & 1 & - & 1 & 1 & 2 & 1 & 2 & - \\
\hline & 9 & 3 & 1 & $\mathbf{1}$ & - & 2 & $I$ & 1 & - & 2 & - \\
\hline & 10 & 1 & 0 & $\mathbf{1}$ & - & 2 & 2 & 1 & - & 2 & 一 \\
\hline \multirow[t]{5}{*}{ P3 } & 11 & 2 & 1 & $\mathbf{I}$ & - & 2 & 1 & 1 & - & 1 & 1 \\
\hline & 12 & 2 & - & - & 1 & 2 & 1 & 1 & 1 & 1 & - \\
\hline & 13 & 0 & 1 & 1 & 1 & 0 & 0 & 0 & - & 2 & - \\
\hline & 14 & 1 & 1 & $\mathrm{I}$ & - & 1 & 1 & 1 & - & 2 & 1 \\
\hline & 15 & 1 & 1 & 1 & - & 0 & 1 & 1 & - & 1 & - \\
\hline \multirow[t]{5}{*}{ Control } & 16 & 1 & 1 & 1 & - & 1 & 0 & 1 & - & 1 & - \\
\hline & 17 & 1 & $\mathbf{I}$ & I & - & I & 1 & 1 & 1 & $I$ & - \\
\hline & 18 & 1 & 1 & 1 & 1 & 1 & 1 & 1 & - & 1 & 1 \\
\hline & 19 & 1 & 1 & 1 & 1 & 1 & 1 & 1 & - & 1 & - \\
\hline & 20 & 1 & 1 & $\mathrm{I}$ & - & I & $\mathrm{I}$ & 1 & - & 1 & - \\
\hline
\end{tabular}

${ }^{*}$ No observations were made; †anovulation.

Table 3. Ovulation rate at each oestrous cycle after booster injection and the treatment group $\times$ cycle number interaction from the analysis of variance

\begin{tabular}{lccc}
\hline Group & \multicolumn{3}{c}{ Cycle number } \\
\hline P1 & 1 & 2 & 3 \\
P2 & $\begin{array}{c}(1.22 \pm 0.20)^{\mathrm{a}} \\
(n=15)\end{array}$ & $\begin{array}{c}(1.41 \pm 0.24)^{\mathrm{a}} \\
(n=11)\end{array}$ & $\begin{array}{c}(1.48 \pm 0.23)^{\mathrm{a}} \\
(n=12)\end{array}$ \\
P3 & $\left(\begin{array}{c}(1.85 \pm 0.21)^{\mathrm{b}} \\
(n=14)\end{array}\right.$ & $\begin{array}{c}(1.24 \pm 0.25)^{\mathrm{a}} \\
(n=10)\end{array}$ & $\begin{array}{c}(1.17 \pm 0.22)^{\mathrm{a}} \\
(n=13)\end{array}$ \\
& $(1.47 \pm 0.22)^{\mathrm{ab}}$ & $(1.04 \pm 0.24)^{\mathrm{a}}$ & $(1.07 \pm 0.24)^{\mathrm{a}}$ \\
$(n=12)$ & $(n=10)$ & $(n=11)$
\end{tabular}

Values are least squares means \pm SEM. Number of observations in parentheses. Within rows or columns, means with different superscripts differ significantly $P<0.01$.

\section{Conception and calving rates}

Ten of the 15 peptide immunized heifers and four of the five control heifers conceived to first service, as determined by ultrasonography at day 45 (Table 4). The remaining six heifers conceived to the second service. Of the six heifers with multiple pregnancies at day 45 , five had two ovulations; four of these 
Table 4. Conception and calving data following breeding after booster injection three

\begin{tabular}{|c|c|c|c|c|}
\hline Group & $\begin{array}{c}\text { Heifer } \\
\text { number }\end{array}$ & $\begin{array}{c}\text { Number of } \\
\text { corpora } \\
\text { lutea }\end{array}$ & $\begin{array}{c}\text { Number of } \\
\text { fetuses at } \\
45 \text { days }\end{array}$ & $\begin{array}{c}\text { Calves } \\
\text { born }\end{array}$ \\
\hline \multirow[t]{5}{*}{$\mathrm{P} 1$} & 1 & 1 & 1 & 1 \\
\hline & 2 & $4(\mathrm{R})$ & 4 & 0 \\
\hline & 3 & $\mathrm{I}$ & 1 & 1 \\
\hline & 4 & 1 & 1 & 1 \\
\hline & 5 & $\mathrm{I}(\mathrm{R})$ & 1 & 1 \\
\hline \multirow[t]{5}{*}{$\mathrm{P} 2$} & 6 & $2(\mathrm{R})$ & 2 & 2 \\
\hline & 7 & 1 & 1 & 1 \\
\hline & 8 & 2 & 2 & 2 \\
\hline & 9 & 2 & 2 & 2 \\
\hline & 10 & 2 & 2 & 0 \\
\hline \multirow[t]{5}{*}{ P3 } & 11 & $I(R)$ & 1 & 0 \\
\hline & 12 & 1 & 1 & 1 \\
\hline & 13 & 2 & 2 & 2 \\
\hline & 14 & $1(\mathrm{R})$ & 1 & 0 \\
\hline & 15 & 1 & 1 & 1 \\
\hline \multirow[t]{5}{*}{ Control } & 16 & 1 & 1 & 1 \\
\hline & 17 & 1 & 1 & 1 \\
\hline & 18 & $\mathbf{1}(\mathrm{R})$ & 1 & 1 \\
\hline & 19 & 1 & 1 & 1 \\
\hline & 20 & 1 & 1 & 1 \\
\hline
\end{tabular}

$R$ : observation from the first repeat oestrus.

produced twin calves at term, whereas the fifth heifer subsequently lost both fetuses. The remaining heifer had four ovulations and had four fetuses at day 45 , all of which were subsequently lost. Two of the nine peptide-immunized, singleovulating heifers, pregnant at day 45, subsequently lost pregnancies. All five single-ovulating control heifers pregnant at day 45 subsequently calved.

\section{Discussion}

This study demonstrates that active immunization of heifers against synthetic peptide sequences of the $\alpha$-subunit of bovine inhibin can increase ovulation rate and twin-calving rate.

The three inhibin peptides used for immunization differed in the ability of the antisera generated to bind to inhibin. Binding was highest for P2, followed by P1, whereas binding for P3 was five times lower than P2. The lower binding for P3 may have been due to conformational differences of this site in the free peptide and native inhibin or to steric hindrance by an iodine atom after inhibin iodination. Peptide 3 has tyrosine residues at positions 116 and 120 , which, if subsequently iodinated in the native molecule, could reduce inhibin binding by antibodies generated against this region of P3. However, the lower binding is most likely the result of an immune response with a lower affinity for P3 compared with either P1 or P2. This is borne out by the fact that the relative magnitude of the immune response is similar among groups, whether measured by enzymeimmunoassay or radioimmunoassay. We are not aware of other studies comparing the immune response in cattle following immunization using different inhibin peptides.

Immunization did not affect either the proportion of heifers showing oestrus or the duration of the oestrous cycle. Price et al. (1987) reported a decrease of one day in duration of the oestrous cycle in heifers immunized against partly purified ovine inhibin, but this may have been due to immunization against other components in the impure inhibin preparation used in their study.

The highest ovulation rate increase was recorded in group P2 in which all heifers responded with an increased ovulation rate at some time. At each of the first oestrous cycles following the second and third booster injections, 4 of $5(80 \%)$ heifers responded with an increased ovulation rate in P2. A total of 11 of $22(50 \%)$ ovulatory cycles with multiple ovulations were recorded in group $\mathrm{P} 2$ following the second and third booster injections of which $10(91 \%)$ were twin ovulatory. Price et al. (1987) reported an increased ovulation rate at the first oestrus after a second booster injection in 3 of 5 heifers immunized with $4 \mathrm{mg}$ of a partly purified ovine inhibin; however, this increase was not repeated after a subsequent booster injection. Schanbacher (1989) reported a mean ovulation rate of $1.9 \pm 0.4$ following immunization of heifers $(n=20)$ with an $\alpha-(1-30)$ porcine inhibin peptide, but there was no indication of the proportion with twin ovulations. Glencross et al. (1990) reported that 4 of 6 heifers immunized with an $\alpha-(1-29)$ bovine inhibin peptide responded with twin ovulations at some time following immunization. An increased ovulation rate $(2.5 \pm 0.4)$ in heifers immunized with an $\alpha-(1-26)$ bovine inhibin has also been reported by Sunderland et al. (1991); however, the response was variable, and the proportion of animals with twin ovulations only was not reported. A superovulatory response with high variability has also been recorded by Bindon et al. (1988) in pubertal heifers (11.6 \pm 3.9 ) and by Hillard et al. (1990) in cows (5.4 \pm 2.7$)$ immunized against a 300 -fold inhibin enriched preparation of ovine follicular fluid.

The relationship between inhibin binding and ovulation rate in the experiment reported here is not clear. Ovulation rate was positively correlated with inhibin binding for group P2 and negatively correlated for group $\mathrm{P} 3$. As peptide titre and inhibin binding were correlated for groups $\mathrm{P} 1$ and $\mathrm{P} 2$, but not $\mathrm{P} 3$, it is possible that the measurement of inhibin binding within individual heifers in group P3 may have been compromised for technical reasons discussed above. It is also clear, however, that the increased ovulation rate cannot be explained by inhibin binding alone, and it is possible that antibodies may have been raised to other $\alpha$-inhibin subunits likely to be involved in the control of ovulation. Ovulation rate was increased in all heifers in group P2 and in only one heifer in group P1, yet inhibin binding was similar for both groups. In addition, 4 of 5 heifers responded with an increase in ovulation rate in group P3, whereas inhibin binding was five times lower than for group P2. Schanbacher (1989) reported a correlation $(r=0.44, P<0.05)$ between ovulation rate in heifers and titre to the $\alpha$-(1-30) porcine peptide, whereas Price et al. (1987) could find no detectable correlation between ovulation rate and antibody titre to the partly purified ovine inhibin used in their study. The failure of heifers with high inhibin binding in group PI to respond with an increased ovulation rate may be due to the inability of the antibodies in these heifers to neutralize biologically active 
inhibin. Forage et al. (1987) found inhibin neutralizing antibodies in only $60 \%$ of ewes immunized against bovine inhibin $\alpha$-subunit, all of which had a higher ovulation rate than the controls. The increase in ovulation rate reported here occurred for the most part in the first cycle after a boost with the incidence of twin ovulations decreasing in subsequent cycles even though inhibin binding was still relatively high, indicating that physiological compensation was occurring as free antibody titres decreased.

The neutralization of biologically active inhibin (increasing pituitary FSH secretion) in cattle by immunization against synthetic peptides from the $\alpha$-subunit may be attenuated for a number of reasons. The ovary secretes large amounts of 'free' inhibin $\alpha$ subunit (Knight et al., 1989; Suginoet al., 1989) and other precursor forms of inhibin containing the $\alpha$-inhibin sequence (Robertson et al., 1989; Sugino et al., 1989). Dimeric and biologically active inhibin may represent only a very small fraction of the total immunoreactive inhibin present in follicular fluid (Beard et al., 1991; Betteridge and Craven, 1991). Groome et al. (1990) found that a polyclonal antibody raised in sheep against the $\alpha$-aminoterminal end [ $\alpha$-(1-29)YG] of bovine inhibin demonstrated a 29-fold greater reactivity (on a molar basis) with the immunizing peptide than with the native $32 \mathrm{kDa}$ form. Knight et al. (1989) and Vaughan et al. (1989) have reported that the $25 \mathrm{kDa}$ free $\alpha$-subunit reacts about 10 -fold better than native $32 \mathrm{kDa}$ inhibin, with polyclonal antibodies raised against the $\alpha$-aminoterminal peptide. FSH concentrations have not yet been measured in the present experiment, and must await detailed analysis at a later date.

There are also indications of a possible role for inhibin and the $\alpha$ subunit of inhibin as autocrine or paracrine regulators of FSH action in the ovary. For example, bovine inhibin has been shown to inhibit rat oocyte meiosis (O et al., 1989), whereas porcine $31 \mathrm{kDa}$ inhibin (Ying et al., 1986) and the amino-terminal fragment of the $\alpha$-chain of porcine inhibin (Hillier et al., 1987) can inhibit FSHinduced rat granulosa cell aromatase activity in vitro. Schneyer et al. (1991) identified a likely competitor of FSH receptor binding (FRBC) in follicular fluid as the $57 \mathrm{kDa} \alpha$-inhibin precursor protein. Immunization in this experiment may have increased pituitary FSH secretion by immunoneutralization of inhibin or by increased $\mathrm{FSH}$ receptor binding at the ovary, thus preventing follicular atresia and an increase in ovulation rate.

Immunization against the peptides had no apparent effect on conception or calving rates. Although the small number of heifers involved in this study does not allow definitive conclusions to be made regarding the effects of immunization on pregnancy rate, the production of four sets of twin calves from six twin ovulatory cycles suggests that peptide immunization is a promising approach to the induction of twinning in cattle. This is the first report of an increase in the twin calving rate following immunization against inhibin.

Although the increase in ovulation rate in this experiment was primarly due to the generation of antibodies to the $\alpha$-inhibin subunit, the exact mechanism(s) by which this increase was mediated is unclear. It is possible that antibodies to inhibin neutralized its negative feedback effect on FSH secretion by the anterior pituitary resulting in increased FSH secretion and an increase in follicular growth. However, an effect of immunization by interfering with the complex local control of ovulation at the ovarian level cannot be excluded.
We thank J. P. Hanrahan for statistical advice and P. Knight (Dept of Biochemistry and Physiology, Reading University, UK) for the generous gift of the inhibin antiserum (H95/2); M. Greally for assisting with inhibin binding studies; P. Joyce, J. Nally, G. Morris and W. Connolly for technical support; G. Burke and P. Creavan for care of the animals. All peptides were obtained from D. Coy, Dept of Medicine, Tulane University Medical Centre, New Orleans, USA. The work was supported in part by Ciba-Geigy Animal Health Ltd, St Aubin FR, CH., Bioresearch Ireland, and Farm Business Development Ltd, Ireland.

\section{References}

Beard AJ, Groome N and Knight PG (1991) Estimation of immunoreactive (ir) inhibin concentrations in bovine ovarian follicles using a novel 2-site immunoradiometric assay (IRMA) specific for dimeric inhibin Journal of Reproduction and Fertility Abstract Series 7 Abstract 40

Betteridge A and Craven P (1991) A two-site enzyme-linked immunosorbent assay for inhibin Biology of Reproduction 45 748-754

Bindon BM, O'Shea T, Miyamoto K, Hillard MA, Piper LS, Nethery RD and Uphill G (1988) Superovulation in pubertal heifers immunized against ovine inhibin purified by monoclonal antibody affinity chromatography Proceedings of the Australian Society for Reproductive Biology 2028

Boland MP, Kane M, Headon D, Williams DH, Goulding D, Sunderland SJ and Roche JF (1991) Persistence of increased ovulation rate in ewes immunized against the $\alpha-1-26$ fragment of inhibin Jourmal of Reproduction and Fertility Abstract Series 7 Abstract 41

Burger $\mathrm{H}$ and Igarashi $\mathbf{M}$ (1988) Inhibin: definition and nomenclature, including related substances Endocrinology 122 1701-1702

Chou PY and Fasman GD (1978) Empirical predictions of protein conformation Annual Review of Biochemistry 47 251-276

Forage RG, Ring JM, Brown RW, McInerney BV, Cobon GS, Gregson RP, Robertson DM. Morgan FJ, Hearn MTW, Findlay JK, Wettenhall REH, Burger HG, and de Kretser DM (1986) Cloning and sequence analysis of cDNA species coding for the two subunits of inhibin from bovine follicular fluid Proceedings of the National Academy of Sciences, USA 83 3091-3095

Forage RG, Brown RW, Oliver KJ, Atrache BT, Devine PL, Hudson GC, Goss WH, Bertram KC, Tolstoshev P, Robertson DM, de Kretser DM, Doughton B, Burger HG and Findlay JK (1987) Immunization against inhibin subunit produced by recombinant DNA techniques results in increased ovulation rate in sheep Journal of Endocrinology 114 RI-R4

Glencross RG, Bleach EC, McLeod BJ, Beard AJ and Knight PG (1990) Increased ovulation rate in heifers immunized against a synthetic peptide sequence of bovine inhibin Journal of Reproduction and Fertility Abstract Series 6 Abstract 30

Greenwood FC, Hunter WM and Glover JS (1963) The preparation of ${ }^{131} \mathrm{I}-$ labelled human growth hormone of high specific radioactivity Biochemistry Joumal 89 114-123

Groome N, Hancock J, Betteridge A, Lawrence M and Craven R (1990) Monoclonal and polyclonal antibodies reactive with the 1-32 amino terminal sequence of the alpha subunit of human $32 \mathrm{~K}$ inhibin Hybridoma $931-42$

Harvey WR (1987) Users guide for LSMLMW. Ohio State University Press, Columbus

Hillard MA, Bindon BM, King B, O'Shea T, Andrews CA and Hinch GN (1990) Superovulation of cows immunized against native ovine inhibin 2 Proceedings of the Australian Society for Reproductive Biology 22134

Hillier SG, Tsonis CG, Wickings EJ and Eidne KA (1987) Inhibition of FSH stimulated granulosa cell function by a synthetic fragment of the porcine $\alpha$ subunit: evidence for involvement of GnRH receptors Journal of Endocrinology 113 R3-R5

Knight PG, Beard AJ, Wrathall JHM and Castillo RJ (1989) Evidence that the bovine ovary secretes large amounts of monomeric inhibin $\alpha$ subunit and its isolation from bovine follicular fluid Journal of Molecular Endocrinology 2 189-200

Kyte J and Doolittle RF (1982) A simple method for displaying the hydropathic character of a protein Journal of Molecular Biology 157 105-132

Mammi S (1989) A microcomputer program to calculate elemental analysis of peptides Computer Methods and Programs in Biomedicine 28 119-120

Mizumachi M, Voglmayr JK, Washington DW, Chen C-LC and Bardin CW (1990) Superovulation of ewes immunized against the human recombinant inhibin $\alpha$-subunit associated with increased pre- and postovulatory folliclestimulating hormone levels Endocrinology 126 1058-1063 
Morris DG, McDermott MG and Sreenan JM (1991) Effect of immunizing prepubertal lambs of low and high ovulation rate genotypes with inhibin partially purified from bovine follicular fluid Theriogenology 35 339-350

O W-S, Robertson DM and de Kretser DM (1989) Inhibin as an oocyte meiotic inhibitor Molecular and Cellular Endocrinology 62 307-311

O'Shea T, Al-Obaidi SAR, Hillard MA, Bindon BM, Cummins LJ and Findlay JK (1984) Increased ovulation rate in Merino ewes and advancement of puberty in Merino lambs immunized with a preparation enriched in inhibin. In Reproduction in Sheep, pp 335-337 Eds DR Lindsay and DT Pearce. Australian Academy of Science, Canberra

Price CA, Morris BA, O'Shea T and Webb R (1987) Active immunization of cattle against partly purified follicular fluid from sheep Journal of Reproduction and Fertility 81 161-168

Robertson DM, Giacometti M, Foulds LM, Lahnstein J, Goss NH, Hearn MTW and de Kretser DM (1989) Isolation of inhibin $\alpha$-subunit precursor proteins from bovine follicular fluid Endocrinology 125 2141-2149

Schanbacher BD (1989) Ovulation response and pituitary FSH charge microheterogeneity in beef heifers vaccinated against synthetic porcine inhibin alpha Journal of Animal Science 67 (Supplement 1) Abstract 876

Schneyer AL, Sluss PM, Whitcomb RW, Martin KA, Sprengel R and Crowley WF Ir (1991) Precursors of $\alpha$-inhibin modulate follicle-stimulating hormone receptor binding and biological activity Endocrinology 129 1987-1999

Sreenan JM and Mulvehill P (1975) The application of long- and short-term progestagen treatments for oestrous cycle control in heifers Journal of Reproduction and Fertility 45, 367-369

Sreenan IM, Morris D, Tait A and Diskin MG (1987) Manipulation of the immune system to increase ovulation rate in the cow. In Follicular Growth and Ovulation Rate in Farm Animals, pp 73-86 Eds JF Roche and D O'Callaghan. Martinus Nihoff, Netherlands
Sugino K, Nakamura T, Takio K, Titani K, Miyamoto K, Hasegawa Y, Igarashi M and Sugino $\mathrm{H}$ (1989) Inhibin alpha-subunit monomer is present in bovine follicular fluid Biochemical and Biophysical Research Communications 159 1323-1329

Sunderland SJ, Goulding D, Kane M, Headon D, Boland MP and Roche JF (1991) Ovarian response in beef heifers following immunization against the $\alpha-1-26$ bovine inhibin fragment joumal of Reproduction and Fertility Abstract Series 7 Abstract 44

Tsonis CG, Pearson M, Hungerford J, Borchers CE, Greenwood PE, Forage RG, Doughton B and Findlay JK (1989) Immunising sheep with recombinant inhibin $\alpha$-subunit increases the number of lambs born Proceedings of the Australian Society for Reproductive Biology 2199

Vaughan JM, Rivier J, Corrigan AZ, McClintock R, Campen CA, Jolley D, Voglmayr JK, Bardin CW, Rivier C and Vale W (1989) Detection and purification of inhibin using antisera generated against synthetic peptide fragments. In Methods in Enzymology, Vol. 168, pp 588-617 Ed. PM Conn. Academic Press, New York

Wrathall JHM, McLeod BJ, Glencross RG, Beard AJ and Knight PG (1990) Inhibin immunoneutralization by antibodies raised against synthetic peptide sequences of inhibin $\alpha$ subunit: effects on gonadotropin concentrations and ovulation rate in sheep Journal of Endocrinology 124 167-176

Ying S-Y (1988) Inhibins, activins and follistatins: gonadal proteins modulating the secretion of follicle-stimulating hormone Endocrine Reviews 9 267-293

Ying S-Y, Becker A, Ling N, Ueno N and Guillemin R (1986) Inhibin and beta transforming growth factor (TGF $\beta$ ) have opposite modulating effects on the follicle stimulating hormone (FSH)-induced aromatase activity of cultured rat granulosa cells Biochemical and Biophysical Research Communications 136 969-975 